\title{
The Civil Attitudes of the Inhabitants of Rural Areas and Their Aspects. Between Declarations and Actions
}

Krystyna Dziubacka / e-mail: krystyna.dziubacka@gmail.com Institute of Pedagogy, University of Wroclaw, Poland.

Dziubacka, K. (2017). Government Help in Upbringing Children and its Significance in the Formation of the Attitudes of Single Parents Towards Employment. Czech-Polish Historical and Pedagogical Journal, 9/2017/2, 56-67. doi: 10.5817/cphpj-2017-0013

Within the framework of these reflections and analysing the declarations of the country-side dwellers concerning their manner of manifesting citizenship, the article tackles the issue of the inaccuracies appearing between the articulated declarations of the level of commitment and the actual action, not only with reference to countryside communities, but also residents of the cities. The deficit, revealed within the awareness and the civil responsibility, provokes the reflection on the effects of socialization and education, as they both shape civic competencies.

Key words: Rural citizenship; citizenship in action; social activity

For years the civil attitudes of Poles - the level and the type of their engagement in social life - have been the subject of empirical investigations. At their basis lies the necessity to follow the directions of the development of democracy in Poland, as well as the necessity to undertake actions facilitating the attempt to "construct socio-cultural characteristics of the structures of a civil society in the Third Republic of Poland", ${ }^{1}$ which has been suggested in a number of publications. The civil society, whose foundation are the individuals who actively participate in public life, who are interested in crucial public issues, ${ }^{2}$ who have

1 Joanna Karczewska states that: "it appears that in the otherwise crucial academic and public question of the definition of the content and the form of the excess or the shortage of civil attitudes in society what ought to be decisive are the diagnoses of concrete civil initiatives, spontaneous and planned, as well as the various types of associations or formal organisations that make up the third sector in Poland". Karczewska J. (2006). Lokalne społeczeństwo obywatelskie (dwie możliwości interpretacyjne). In Społeczności lokalne. Teraźniejszość i przyszłość. Eds. Jałowiecki, B. - Łukowski, W. SCHOLAR, Warsawa: pp. 11-38.

2 Putnam, R. (1993). Making Democracy Work. Civil Traditions in Modern Italy. Princeton: Princeton University Press, p. 87. 
clearly defined views on public affairs, who can defend their beliefs while respecting the beliefs of the opponents, who actively participate in the work of the associations which express these views, ${ }^{3}$ are a sine qua non condition of the increase in the democratisation of social life, as well as the progress of the country itself. This explains the importance that the problems of civil society have in the work of researchers. It also becomes the source of the present analyses, in which we focus on the character of the civil attitudes in the selected rural environment while outlining the tendencies in changes.

Making the civil attitude the theoretical basis of the present paper with regard to its definition I limit myself to the necessary minimum while pointing out that society is considered civil when "its members organise themselves in communities and social organisations in order to address the problems that they themselves or other citizens have, and social relations are based on trust and cooperation". ${ }^{4}$ It is, therefore, a state of affairs in the country and in the society in which "citizens have influence on the actions of the government and they can control it, and simultaneously they enjoy the right to undertake their own initiatives and organise themselves in numerous ways". 5 That is why the civil attitude is connected with a responsible understanding of reality which "not only allows one to make proper decisions and a proper set of behaviour, but which also make one free in their choices. It establishes, therefore, the basic condition for the acquiring a sense of civic duty". ${ }^{6}$ The above are expressed in activity based in the need for conscious participation of an individual in organising social life, which is, in turn, a consequence of experiencing civil attitude (the models of behaviour of the present and of the past), the behaviours chosen by citizens-representatives of the society, the results of the work of the mechanisms of democracy, knowledge of systems, and results of political choices. ${ }^{7}$ For the civil attitudes formed thus (the sense of duty and the resultant preparedness to act) what is also important are the situations in which individuals find themselves out of their own will or in which they are placed. "In such

3 lbid., p. 89.

4 Wciórka, B. (2005). Społeczeństwo obywatelskie na przełomie wieków. In Polska. Europa. Świat. Opinia publiczna w okresie integracji. (Eds.) K. Zagórski, M. Strzeszewski, Warszawa, p. 261

5 Krzemiński, J. (2005). Społeczeństwo obywatelskie i symbole wspólnoty. In M. Drogon (Ed.) Jak Polacy przegrywają. Jak Polacy wygrywają, Gdańsk, p. 95.

6 Ferenz, K. (2007). Patriotyzm i powinności obywatelskie. In A. Szerląg (Ed.) Edukacja obywatelska w społeczeństwach wielokulturowych. Wyd. Kraków, Impuls, s. 29. Ibid. 
circumstances the differences in the understanding of group interests becomes important: social, regional, and ethnic, resulting from different systems of values, or only of their hierarchies or the choice of the manner of their realisation". ${ }^{8}$ To the list of civil actions, apart from participation in elections, membership in organisations and participation in their meetings, assuming positions in organisations, one needs to add the work for communities. The latter, while reinforcing the sense of belonging, facilitates the forming of regional identity - a factor that is essential on the forming of local communities. To recapitulate, let us mention the belief formulated by P. Gliński that the members of a civil society need to represent certain values connected with economy (honesty, entrepreneurship), to abide by law, and to have the ability to function in public life (to establish associations, to have the sense of belonging to a group, to take care of one's affairs), ${ }^{9}$ to act responsibly in relation with the state and take into account the good of the public when making decisions. At the same time, in the attempts at characterising a particular community in relation to their civil attitudes, a question is asked pertaining to honesty, responsibility, ability to cooperate, sense of duty, rational approach to problems, and pragmatism of its members, ${ }^{10}$ as well as whether they become "increasingly sensitive to the common good, do they organise themselves more often to co-create the world around them, and, first and foremost, to solve the current social problems". ${ }^{11}$ The search for the answer to the above questions is, on the one hand, an attempt to present the ways of carrying out civil duties and the character of the presented attitudes, and on the other, to define the direction of the changes that take place in this area in the context of their compliance with what society expects. This is also the aim of the present paper which focuses on civil duties that are carried out by a selected local community. The research which serves this purpose was conducted in 13 villages in Bogatyński region, located in south-western Poland (Bogatynia commune, Lower Silesian voivodeship), where the borders of Poland,

8 Ferenz, K. as in p. 29.

9 Gliński, P. Developing of the Third Sector as a Vehicle of Civil Society In Poland, quoted after Kłoczko, A. Gajewską. Aktywność obywatelska na wsi - studium przypadku czterech wsi na Podlasiu, p. 122.

10 Sadowski, A. (2005). Kapitał społeczny i kulturowy heterogenicznej "metropolii” wschodniego pogranicza. In B. Jałowiecki, A. Majer, M. S. Szczepański (Eds.) Przemiany miasta. Wokół socjologii miasta Aleksandra Wallisa, Warszawa, p. 259.

11 Wciórka, B. (2005). Społeczeństwo obywatelskie na przełomie wieków. In Polska. Europa. Świat. Opinia publiczna w okresie integracji. K. Zagórski, M. Strzeszewski. (Eds.) Warszawa, p. 259. 
Germany, and Czech Republic meet. It is, therefore, a borderland (understood here in the geopolitical sense), and it is industrially developed. When relating to the significance of both these features in the formation of civil attitudes let us point out that the socio-political atmosphere of this borderland has for a long timed failed to facilitate the shaping of a positive relation with the region as "one's own place" which, in turn, led to the lack of engagement in affairs crucial to the place of residence such as, e.g., protection of the cultural environment (artefacts of the culture of Lusatia). What is more, the quality of human capital (among others, the low level of education) - a factor connected with the labour market - would determine the low level of civil awareness and the competences pertaining to care for the common good.

The empirical material which constitutes the basis of the present paper was collected in 1993 and 2010. The analyses of the data have been supplemented with the results of the research carried out in 2016 in the same region. The problems outlined during the investigation shall be presented in the further part of the present paper.

\section{Civil attitudes in rural areas and the civil attitudes of Poles}

The main thesis here is the conviction, constructed on the basis of reference sources, that the level of civil engagement of Poles is low. Among the factors conditioning the above one needs to refer to the experiences of the past: the times of real socialism when work for the community and membership in organisations was highly ideological, and the domination of the state "made it difficult for citizens to cooperate with government authorities or even the local administration". The model of citizenship defined by contemporary ideology did not have much in common with "self-government", "engagement", "entrepreneurship", or "grassroots initiative", and it served to form the attitude of a "demanding taker" rather than a "giver". In the first period of the political transformation in Poland the low parameters of human capital that shaped the attitudes have made it significantly more difficult for certain social groups to actively adapt to the change. What was also important were the later experiences of after 1989 which undermined the trust in political institutions such as the parliament, political parties, and public authorities. ${ }^{12}$ It is possible that all these factors combined and separately

12 Kłoczko-Gajewską, A. Aktywność obywatelska na wsi-studium przypadku czterech wsi na Podlasiu, p.122. 
in their own specific ways have led to the fact that in spite of the numerous years of the stabilisation of the relations between the society and the state and gaining experiences in cooperation between citizens and the authorities on various levels the level of civil engagement is still considered unsatisfactory. If we characterise it on the basis of, e.g., the Social Diagnosis of 2015, then apart from the little importance attributed to social $(4 \%)$ and political $(6 \%)$ activity in the hierarchies of values created by Poles, what is also noticeable is the low level of the sense of competence, authorship, and trust in the authorities. What is more, as J. Czapiński points out "in Poland the people who wish to do something for their communities do not like to get formally organised: it is enough that they take certain 'actions for the good of their communities'. Research shows, however (as the author states further) that this phenomenon is as rare as membership in organisations". ${ }^{13}$

It needs to be added that in 2015 13.4\% of Poles declared that they were members of organisations, $15.4 \%$ declared that they worked for others, and $19.4 \%$ declared participation in public meetings. ${ }^{14}$

Graph 1: Selected indicators of the civil attitudes of Poles.

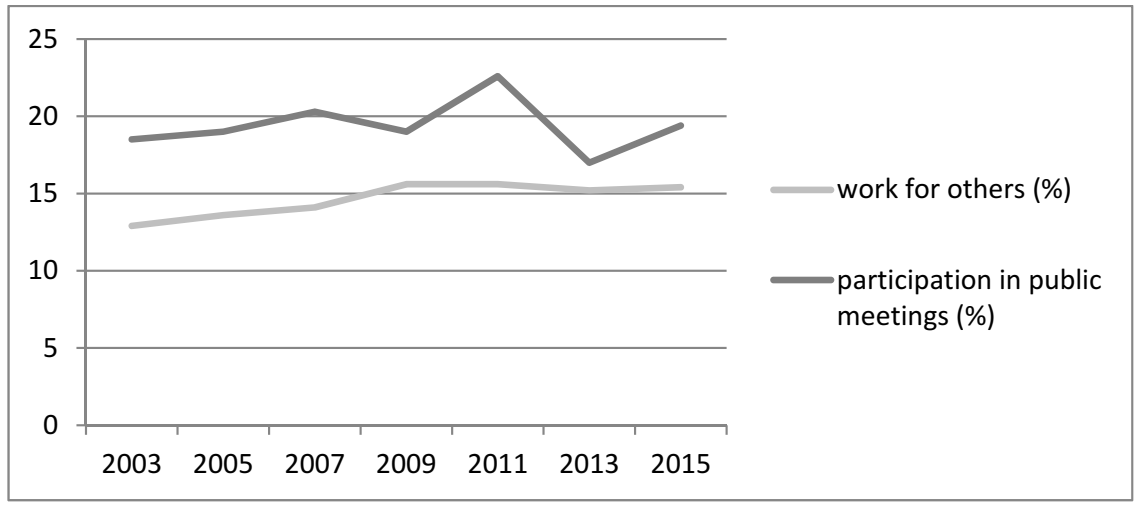

Source: developed on the basis of Social Diagnosis 2015

What is crucial from the perspective of the discussed problems is that with the generally low level of civil engagement of Poles the parameters (indicators) thereof, including the culture and civil awareness in rural

13 Czapiński, J. - Panek, T. Diagnoza społeczna 2015], Warszawa, WSFiZ, 2015, pp. 326-330. lbid. 
areas (with the traditionalism and conservatism of their views) they have been and remain less satisfactory than in urban environments. ${ }^{15}$ The research conducted throughout the years confirmed the weaker level of indication in those communities of low parameters of human capital, marginalised as a result of the economic and social changes, ${ }^{16}$ that is, in rural communities where GDP per capita, the level of enrolment, and average life expectancy have remained lower than in cities. ${ }^{17}$ To balance against these negative assessments a belief is presented that the character of civil engagement of the inhabitants of rural areas ought not only be perceived through their formal membership in organisations and associations, ${ }^{18}$ or through their participation in elections for higher government levels. What needs to be noticed in rural communities are the informal forms of collective activities, such as helping neighbours, common work for the good of the local communities, and nurturing traditions and customs. However, even in relation to these indicators civil attitudes vary greatly in different regions, which is conditioned by history and/or directions of economic development. Their importance for the character of civil engagement of local communities in rural areas will be presented on the basis of the analysis of the results of my research.

\section{Civil attitudes of the inhabitants of rural areas in light of research results}

The foundation for the present paper are the results of research carried out in 1993. In its assumption it pertained to the quality of life of the inhabitants of rural areas experiencing the effects of the transformation. What was then presented was as the low position that the research participants attributed to social and political activity in the hierarchies of values that they established. Furthermore, the declared character of the attitudes (e.g. electoral activity) was far from the expected level of engagement in the issues crucial for the functioning

15 Raport o rozwoju społecznym Polska 2000. Rozwój obszarów wiejskich. (2000) Ed. K. Gorlach. UNDP, Warszawa, UNDP, p. 3. Cf. e.g. Goszczyński, W. - Kamiński, R. Knieć, W. (2013). Dylemat linoskoczka, czyli o profesjonalizacji autentyczności i perspektywach rozwoju organizacji pozarządowych na wsi i w małych miastach.Wydawnictwo. Toruń-Warszawa, FAOW.

16 Broda-Wysocki, P. (2003). Rozwój społeczeństwa obywatelskiego w Polsce. Analiza na przykładzie regionów koszalińskiego i opolskiego. Warszawa, IPiSS, p. 51.

17 Kłoczko-Gajewska,A. Aktywność ... op. cit.

18 Positive examples of the above can be found in e.g. Kłodziński, M. (2006). Aktywizacja spoteczno-gospodarcza gmin wiejskich i małych miast. Warszawa, IRWiR PAN. 
and the development of the region. What is crucial is that the results did not significantly differ from the results of nationwide research which focused additionally on the analysis of their conditioning. The period between the measurements in 1993 and 2010 is the time of changes manifested in the area of civil engagement of the particular investigated groups, but also in the factors that would determine them, such as e.g. human capital. When taking into account only the changes connected with the education of the research participants what becomes visible is the increase in its level: in the first measurement the majority of the respondents had primary and vocational school education $(70.7 \%)$, and in the second one the largest group was comprised of respondents with secondary school education (45.5.\%). Furthermore, the number of individuals with higher school degrees increased from 5.3\% to $10.3 \%$. Placing emphasis on this aspect results from the conviction that the increase in the above leads to the rise in cultural and civilisation competences as well as civil awareness. A factor conditioning the particular attitudes is also the place of birth of the respondents with attention paid to whether they were born in or outside the region. I connect this variable with the declared level of identification of the respondents with their place of residence as "their own place" and with the ways in which they are evaluated. The respondents born outside the region would state that their residence there is forced and temporary ("as long as there's work") and does not oblige them to engage in the problems of the local communities. At the same time, what was favourable to the increase of social engagement were the changes in this variable: while in the first measurement the percentage of the respondents born outside the region (61\%) was nearly twice higher than that of those native to the area (Żytawianie) $(39 \%),{ }^{19}$ the results of the measurement in 2010 showed a reversal of these proportions: $32.2 \%$ were migrants and $67.5 \%$ of the respondents were born in the region. In relation to this the evaluation of living in the area was changed: while in the measurement from 1993 only 10.8\% perceived the region as an attractive place to live, in 2010 positive opinions (63\%) were decisively more numerous than negative evaluations. Apart from the significant increase in the parameters of human capital in its particular areas improvements in quality of social capital were also registered. The

19 The region of the Bogatynia commune is also called the turoszowski region (from the name of the industrial plant constructed in the area of the village Turoszów) or the Żytawski bulge because of its geographical location (the Żytawskie hills) and the specific outline of the state borders. 
changes were manifested in the declared engagement in social life, the awareness of local problems, and readiness to act. These changes contrasted positively with the results of the first measurement (1993), where the low importance attributed by the respondents to social $(7.8 \%)$ and political (6.6\%) activity, the lack of trust in institutions and organisations, expressed in attributing bad intentions onto them, as well as social activity remaining at $1.1 \%$ - as measured according to the declared participation in local organisations - were presented. What is significant, however, is that even then, in the initial stages of the transformation, when as a result of the changes in social, economic, and political face of the region the living conditions of its inhabitants would deteriorate, they showed awareness of the local problems. In the questions gauging the level of awareness of the local specificity, $41.5 \%$ of respondents recognised the slogan "Euroregion Nysa" and had heard of the international cooperation undertaken by the organisation, and 40.4\% declared understanding and acceptance of combined Polish and German initiatives. $65.8 \%$ of all the respondents were able to point out the most important problems of their place of residence which needed to be solved by the local government administration. Following list of the postulates to the authorities comprised of expectations facilitating:

- improvement of the natural environment in the region (23.9\%);

- development of positive relations between the neighbouring nations $(17 \%)$;

- removing the restrictions pertaining to movement across the borders for the local populations (14.5\%);

- dealing with social problems (8.1\%);

- improvements in the state of culture, protecting the monuments of local culture (7.2\%);

- boosting the activity of companies on both sides of the border (7.2\%);

- finding work abroad (mainly in Germany) for the local population $(5.1 \%) .^{20}$

This is significant because of the level of the recognition of the specificity of the region on the one hand and character of the formulated postulates on the other. Their demanding character appeared typical of a population formed in the previous political system and not yet altered by the reforms that were able, in time, to awaken the dormant will to selfgovern and be active.

What is noticeable in the presented results of the research of 2010 into the changes that took place in area of civil engagement is the manner of

20 Results of the measurement in 1993. 
the valuation of social activity by the enquired inhabitants of the region. Significant increase in the importance thereof (from $7.7 \%$ to $18.2 \%$ ) appears to positively influence the declared engagement in social and political life. They were measured with the same indicators as in the case of participation in elections and referendums, membership in organisations and the served social functions, activity promoting the inhabited region, and awareness of local problems. And so, participation in national elections was declared by $59.7 \%$. The level of declaration of participation in elections for the local government and other local elections increased to $65.2 \%$. Although participation in social organisations and readiness to work for them were declared by $9.7 \%$ of the respondents only, in comparison with the aforementioned social activity at the level of $1.1 \%$ (in 1993) it proves a rise in the engagement. Increase in the sense of authorship facilitated this tendency - it was presented in $26.6 \%$ of the responses. What is more, the respondents were able to divide the problems into those that needed to be solved by the government administration (80.8\%) and those that called for the actions of the inhabitants themselves (67\%). Although the number of the problems that were perceived as requiring government intervention, was still higher that of those that could be solved by the people one can without a doubt, in light of the results from 1993, when the formulated expectations were in fact directives, state that civil awareness in the region has indeed grown. ${ }^{21}$

The respondents declared participation in the actions organised by Great Orchestra of Christmas Charity, preserving the natural environment (recycling, collecting dead batteries), or that through participation in local festivals they supported the promotion of a particular village or the region. As the respondents themselves pointed out, their activity in this area was frequently inspired by the engagement of their children or grandchildren, however, it was crucial that they were able to define the undertaken initiatives and actively participate in them.

The quality of social capital of the inhabitants of a region is also indicated by their declared preparation to become engaged in initiatives which due to the history of the region, the political climate, and the low level of human capital could not be carried out in the previous decades. These initiatives include organised meetings of the inhabitants of the

21 See: Michalska, S. (2008). Aktywność społeczna i postawy obywatelskie mieszkańców wsi a rodzaje ich życiowych orientacji. In Społeczne aspekty zrównoważonego rozwoju wsi w Polsce. Partycypacja lokalna i kapitat spoteczny. Eds. H. Podedworna, P. Ruszkowski. Warszawa: Scholar, pp. 123-142. 
Graph 2: Changes in the valuation of "social activity" and "political activity" over the years.

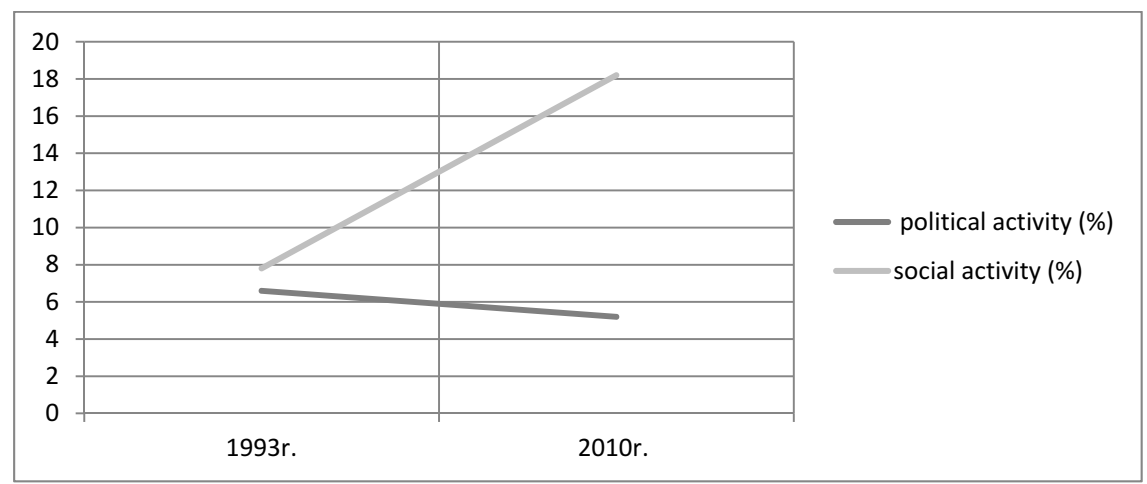

Source: the author's research

Graph 3: Selected indicators of civil attitudes of inhabitants of rural areas in 2010.

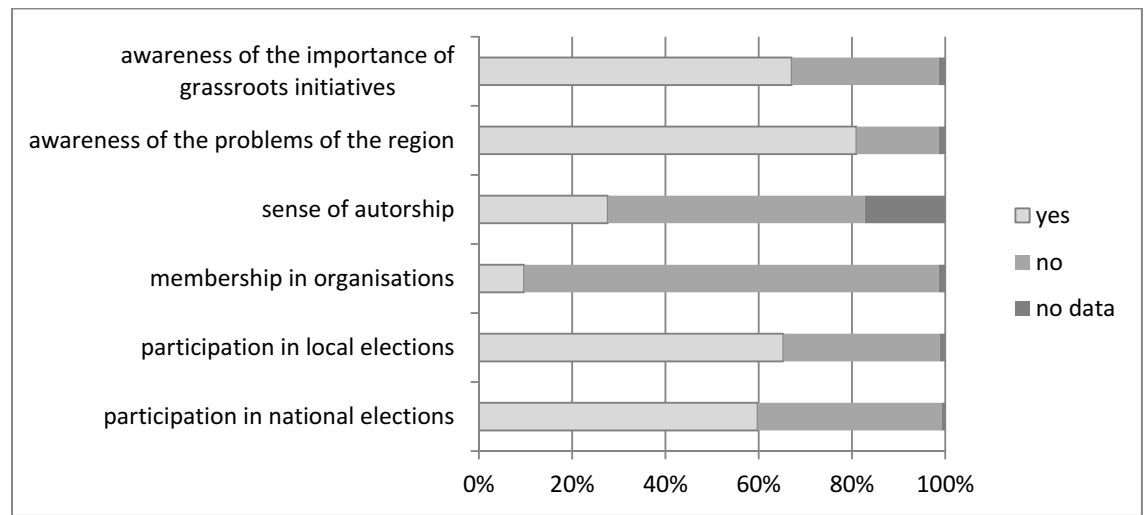

Source: the author's research

particular villages with the former (pre-war) citizens of these lands (their families), taking care of the monuments to the German soldiers fallen in World War I, and the cataloguing and renovation of the architecture typical of the region. The declared preparedness to participate in various initiatives promoting the culture of the land, e.g. the organised days of the "Open doors of Upper Lusatian Houses", is significant. As part of this event held by local organisations the history of the region is taught and 
instructions pertaining to the renovation and protection of the historic buildings are provided. When presenting the character and the direction of the changes one ought to notice that while in the measurement of 1993 the heritage of Lusatian culture in the form of the Upper Lusatian House (Umbingenhaus) was perceived as alien (German) and not valued positively, in the measurement of $201021.7 \%$ of the respondents mentioned it as a typical and unique element of the cultural landscape of their place of residence. Its value was connected with, among others, the fact that it builds the identity of the region and as it is an element of its promotion as it serves to raise individual economic activity of its inhabitants (in e.g. tourism and hospitality), and as a result has positive influence on their living conditions. This pragmatism with traits of entrepreneurship is the last of the enumerated indicators of civil attitude. And while we may not present differences in the valuation of individual entrepreneurship and the declared preparedness to undertake economic initiatives through the years $(21.1 \% 2010)$, it is worth emphasising that their potential increase will facilitate the implementation of the paradigm of diversification of the sources of income of the households in rural areas.

\section{Between declarations and actions - observations and final remarks}

The picture of the changes in the area of civil engagement of the inhabitants of rural areas that has been constructed on the basis of research conducted with a 17-year interval allows us to formulate a thesis of the increase in the value of social capital in the investigated region. It results in a rise in civil engagement. The discovered optimism is, however, contradicted by the frequent lack of consistency between the declarations of the respondents and their actual level of civil engagement, which is emphasised in references. This is registered in the attempts of both a qualitative and a quantitative measurement of the work of non-governmental organisations ${ }^{22}$ as well as in the research into the preparation of the particular groups of respondents to participate in presidential and parliamentary elections. ${ }^{23}$ Although the problems of the

22 Goszczyński, W. - Kamiński, R. - Knieć, W. (2013). Dylemat linoskoczka, czyli o profesjonalizacji autentyczności i perspektywach rozwoju organizacji pozarządowych na wsi i w małych miastach. Toruń-Warsaw, Wydawnictwo FAOW.

23 www.parlamentarny.pl/badania-opinii-i-rankingi/frekwencja-wybory-parlamentarne-205ilu-wyborcow-zaglosuje,1478.html (retrieved: 09. 01. 2017). 
consistency of the declarations of the respondents in the area of the methods of the realisation of civil attitudes and their acts is not the subject matter of the present paper it ought to be supplemented by data collected in 2016. The aim of the research quoted was the analysis of the attitude of the inhabitants of the Bogatynia region to the cultural heritage of Upper Lusatia, with the post-war inhabitants of the area as its inheritors. Insufficient care was taken to protect the houses that were not practically attractive (low standard), damaged through "incompetence of their inhabitants" as well as the flood in 2010 from further devastation and $\operatorname{arson}^{24}$. In the conducted research it was significant that a number of respondents were indifferent to the fate of the local historical buildings. $18 \%$ of them emphasised that the buildings found in the city (and not only those which have suffered during the flood) are not worth the time and the effort to save them. A group of respondents would mention their understanding of the acts of vandalism which were justified by individual economic gains. Therefore, alongside the positively evaluated increase in civil engagement of the inhabitants of the rural areas in the discussed region there appeared permissivism and "uncivil" pragmatism. These make one doubt the consistency of the discovered attitudes with the socially acceptable models of civil culture, and the lacks discovered in the area make one reflect on the achievements in the socialisation in the course of which civil competences are acquired.

Let the conviction that the quality of civil attitudes of the particular groups is the product of the process of upbringing and education serve as the conclusion of the present paper. The formation of these attitudes begins in the family environment. Observation of the deeds of the parents in such situations as helping others, expressing the preparedness and the skills to act, or abiding by moral rules in social life facilitate the perception of their stance as a source of inspiration. The schools, as well, as institutions of secondary socialisation are responsible for shaping civil knowledge and raising awareness of the range of rights and duties of each member of a community. And then there are the representatives of the society who realise their obligations towards the society: within them lies the responsibility for the respect for the law and affirmation of the conviction that the state is a common good of all the citizens, and formation of attitudes that make one responsible for taking actions towards the common good is the fundamental aim of civil attitudes.

24 Dziubacka, K. Artefakty kultury lokalnej w doświadczeniach polsko-niemieckiego pogranicza. Uwarunkowania kształtowania postaw wobec dziedzictwa kulturowego Górnych Łużyc. Multicultural Studies, Tom II (2/2016). 